\title{
Deviated VH4 immunoglobulin gene usage is found among thyroid mucosa-associated lymphoid tissue lymphomas, similar to the usage at other sites, but is not found in thyroid diffuse large B-cell lymphomas
}

\author{
Yumiko Sato ${ }^{1}$, Naoya Nakamura ${ }^{2}$, Satoko Nakamura ${ }^{1}$, Sumie Sakugawa ${ }^{3}$, Koichi Ichimura ${ }^{1}$, \\ Takehiro Tanaka ${ }^{1}$, Nobuya Ohara ${ }^{1}$, Takeshi Oka ${ }^{1}$, Eisaku Kondo ${ }^{1}$ and Tadashi Yoshino ${ }^{1}$ \\ ${ }^{1}$ Department of Pathology, Okayama University Graduate School of Medicine and Dentistry, Okayama, Japan; \\ ${ }^{2}$ First Department of Pathology, Fukushima Medical University School of Medicine, Fukushima, Japan and \\ ${ }^{3}$ Department of Internal Medicine, Okayama Citizens' Hospital, Okayama, Japan
}

\begin{abstract}
It remains unclear whether or not diffuse large B-cell lymphomas of extranodal sites arise from mucosaassociated lymphoid tissue (MALT) lymphomas. We studied the clinicopathological features of MALT lymphoma and diffuse large B-cell lymphoma in the thyroid gland, with special reference to VH usage of immunoglobulin gene rearrangement, to clarify the relationships between these two types of lymphomas. In addition, $\mathrm{t}(11 ; 18)(\mathrm{q} 21 ; \mathrm{q} 21)$ translocation was examined by multiplex reverse transcription-polymerase chain reaction. We examined 58 patients with primary thyroid lymphoma: 31 (male seven and female 24) with MALT Iymphoma and 27 (male three and female 24) with diffuse large B-cell lymphoma. Interestingly, the sequence of $\mathrm{VH}$ genes revealed that the two subtypes differed significantly in their use of the VH4 family $(P<0.05)$. Of the seven MALT lymphomas, three used the VH4 family and the other four used the VH3 family, whereas eight out of nine diffuse large B-cell lymphoma used the VH3 family, one used the VH1 family, and none used the VH4 family. It was also interesting that, in one diffuse large B-cell lymphoma patient with MALT lymphoma, the diffuse large B-cell lymphoma component used the VH3 family and the MALT lymphoma component used the VH4 family. These data imply that, in a subset of cases, these two subtypes do not share a common origin and that at least some diffuse large B-cell lymphomas have a de novo origin. No $t(11 ; 18)$ (q21; q21) was detected in thyroid lymphomas, which are different from MALT lymphoma of the stomach, lungs, large intestine and ocular adnexa. This strongly indicated that the presence of $t(11 ; 18)$ (q21; q21) in MALT lymphoma is organ-specific.
\end{abstract}

Modern Pathology (2006) 19, 1578-1584. doi:10.1038/modpathol.3800692; published online 15 September 2006

Keywords: diffuse large B-cell lymphoma; mucosa-associated lymphoid tissue lymphoma; PCR; RT-PCR; thyroid gland; $\mathrm{VH}$ family

Primary thyroid lymphoma is an uncommon type of tumor. A majority of thyroid lymphomas are of the B-cell type, most of which are diffuse large B-cell lymphomas or mucosa-associated lymphoid tissue (MALT) lymphomas. ${ }^{1}$ MALT lymphoma is the second most frequent type of lymphoma in Japan. ${ }^{2}$ In our surgical files, thyroid MALT lymphomas

Correspondence: $\mathrm{Dr} \mathrm{T}$ Yoshino, $\mathrm{MD}, \mathrm{PhD}$, Department of Pathology, Okayama University Graduate School of Medicine and Dentistry, 2-5-1 Shikata-cho, Okayama 700-8558, Japan.

E-mail: yoshino@md.okayama-u.ac.jp

Received 17 January 2006; revised 30 July 2006; accepted 31 July 2006; published online 15 September 2006 comprise $4 \%$ of all MALT lymphomas. MALT lymphoma arises in acquired MALT associated with chronic inflammatory processes triggered by autoimmune phenomena and/or chronic infection. In the thyroid gland, Hashimoto's thyroiditis is thought to be associated with the development of MALT lymphoma. ${ }^{3,4}$ Occasionally, a component of MALT lymphoma is associated with diffuse large B-cell lymphomas. Thus, some diffuse large B-cell lymphomas have been thought to arise from pre-existing MALT lymphomas. Genetic or immunohistochemical evidence for a clonal link between MALT lymphoma and diffuse large B-cell lymphoma in some gastric patients has been reported., 
However, the relationship between MALT lymphoma and diffuse large B-cell lymphoma remains to be clarified. Recently $\mathrm{t}(11 ; 18)(\mathrm{q} 21 ; 21)$ was found to be a specific chromosomal translocation associated with MALT lymphoma, ${ }^{7-9}$ and it was proposed that gastric MALT lymphomas with this abnormality do not show large-cell transformation. ${ }^{10}$ In addition, variable frequencies of $t(11 ; 18)(q 21 ; q 21)$ of MALT lymphomas from different sites suggest different premalignant diseases associated with MALT lymphoma. ${ }^{11}$ To determine the relationship between MALT lymphoma and diffuse large B-cell lymphoma in the thyroid gland, we studied the clinicopathological features of MALT lymphomas and diffuse large B-cell lymphoma in the thyroid gland with special reference to $\mathrm{VH}$ usage by the immunoglobulin gene. We also examined the $t(11 ; 18)$ (q21; q21) translocation of thyroid lymphomas by using multiplex reverse transcription-polymerase chain reaction (RT-PCR).

\section{Materials and methods}

\section{Patients}

Formalin-fixed, paraffin-embedded tissues or frozen tissues from 31 patients with MALT lymphoma and 27 patients with diffuse large B-cell lymphoma of the thyroid gland were retrieved from the pathology files at the Okayama University Graduate School of Medicine and Dentistry and Fukushima Medical University between 1989 and 2004. The records of all patients were reviewed to confirm the histological diagnosis according to the World Health Organization Classification criteria. ${ }^{12}$ We diagnosed the cases as Hashimoto's thyroiditis when they showed diffuse lymphocytic infiltration between the thyroid follicules around the lymphoma and/or our laboratory findings showed positive for antithyroid antibody. All patients were Japanese. Lymphomas that involved the thyroid gland secondarily were not included in the study. Samples from each patient were used for molecular analysis and immunohistochemistry. Patients underwent a standardized informed consent procedure.

\section{Immunohistochemistry}

To confirm the diagnosis of MALT lymphoma and diffuse large B-cell lymphoma, immunohistochemistry was performed on formalin-fixed, paraffin-embedded sections using the indirect immunoperoxidase method with secondary antibodies conjugated to peroxidase-labeled dextran polymer (EnVision ${ }^{+}$, DAKO Japan, Kyoto, Japan). In brief, 4- to 6- $\mu$ m-thick sections were deparaffinized and rehydrated. After endogenous peroxidase activity was blocked by $3 \% \mathrm{H}_{2} \mathrm{O}_{2}$, antigen was retrieved by heat treatment for $30 \mathrm{~min}$ in $10 \mathrm{mM}$ citrate buffer at $\mathrm{pH}$ 6.0. The slides were incubated for $10 \mathrm{~min}$ in $10 \%$ normal goat serum, then incubated overnight at $4^{\circ} \mathrm{C}$ with primary monoclonal antibodies against the following antigens: CD20 (1:200) and CD79a (1:40), purchased from DAKO Japan; and CD5 (1:25) and CD10 (1:50), from Novocastra Laboratories (Newcastle, UK). The specimens were then treated with the Envision ${ }^{+}$ immunostaining system according to the manufacturer's instructions. Diaminobenzidine was used for color development, and hematoxylin was used for counterstaining.

\section{DNA Amplification and Analysis of Nucleotide Sequences}

The immunoglobulin heavy chain $(\mathrm{IgH})$ gene was amplified by seminested polymerase chain reaction (PCR) as previously described. ${ }^{13}$ The primers used in this study were as follows: $5^{\prime}$-TGG[A/G] TCCG[C/ A] CAG [G/C] C [T/C][T/C] C [A/C/G/T] GG-3', as the upstream consensus $\mathrm{V}$ region primer (FR2A); $5^{\prime}$-TGAGGAGACGGTGACC- ${ }^{\prime}$, as the consensus J region primer (LJH); and $5^{\prime}$-GTGACCAGGGT [A/C/ G/T] CCTTGGCCCCAG-3', as the consensus J region primer (VLJH). The amplified product from each patient was electrophoresed on a $3 \%$ agarose gel and visualized by transillumination following ethidium bromide staining. PCR products of appropriate lengths (220-330 bp) were isolated. DNA was recovered from the clonal bands and directly sequenced using the ABI PRISM 3100 Genetic Analyzer (Applied Biosystems Japan, Tokyo, Japan) with Big Dye terminators (Applied Biosystems Japan). Sequences were compared with the germline sequences using the Ig BLAST site (http:// www.ncbi.nlm.nih.gov/igblast/).

\section{Detection of $t(11 ; 18)(q 21 ; q 21)$ Chromosomal Translocation}

$\mathrm{t}(11 ;$ 18) (q21; q21) chromosomal translocations were detected using the multiplex RT-PCR method as described previously. ${ }^{14}$ Briefly, $3-\mu \mathrm{m}$-thick, deparaffinized sections were incubated in digestion buffer (20 mM Tris, pH 8.0, $20 \mathrm{mM}$ EDTA, 1\% SDS, and $1 \mathrm{mg} / \mathrm{ml}$ proteinase $\mathrm{K}$ ) at $56^{\circ} \mathrm{C}$ overnight. Total RNA was extracted using TRIZOL LS (Invitrogen Japan, Tokyo, Japan). RNA was subjected to firstround multiplex RT-PCR, then to second-round nested multiplex PCRs (three parallel; second PCR $\mathrm{A}, \mathrm{B}$, and $\mathrm{C}$ ). The final PCR products were electrophoresed on a $3 \%$ agarose gel and visualized by transillumination following ethidium bromide staining.

\section{Statistical Analysis}

Fisher's exact probability test was used to compare clinical data and $\mathrm{VH}$ family usage between MALT lymphomas and diffuse large B-cell lymphomas. 


\section{Results}

\section{Clinical Features of Malignant Lymphoma of the Thyroid Gland}

Clinical data for each patient are summarized in Table 1. As the table shows, there were 31 MALT lymphomas (male seven and female 24) and 27 diffuse large B-cell lymphomas (male three and female 24). The mean ages of MALT lymphoma and diffuse large B-cell lymphoma patients were 67.8 (range 43-86) and 70.3 (range 45-88), respectively. Out of 58 patients, 36 (22 with MALT lymphomas, 14 with diffuse large B-cell lymphomas) showed Hashimoto's thyroiditis. Thirteen cases (12 of MALT lymphomas and one of diffuse large B-cell lymphomas) were diagnosed based on histological parameters and 23 cases (10 of MALT lymphomas and 13 of diffuse large B-cell lymphomas) were on clinical parameters. Patients were treated by various methods: surgical excision only $(23.3 \%)$, chemotherapy $(18.6 \%)$, radiation $(11.6 \%)$, or some combination of these methods (44.2\%). Only one patient with MALT lymphoma was observed without receiving any therapy. Follow-up data were obtained for 40 patients (22 with MALT lymphomas and 18 with

Table 1 Summary of clinical features of thyroid lymphomas

\begin{tabular}{|c|c|c|c|}
\hline & $\mathrm{N}$ & $D L B C L$ & $M A L T$ \\
\hline No. of cases & 58 & 27 & 31 \\
\hline Mean age (years) & 58 & $70.3(45-88)$ & $67.8(43-86)$ \\
\hline Gender & 58 & & \\
\hline Male & & 3 & 7 \\
\hline Female & & 24 & 24 \\
\hline Serum $L D H$ & 38 & & \\
\hline Elevated & & 8 & 4 \\
\hline Normal & & 11 & 15 \\
\hline Antithyroid antibody & 26 & & \\
\hline Positive & & 10 & 13 \\
\hline Negative & & 2 & 1 \\
\hline Stage & 55 & & \\
\hline I E & & 16 & 18 \\
\hline II E & & 9 & 11 \\
\hline IV & & 1 & 0 \\
\hline Treatment & 43 & & \\
\hline Op & & 3 & 7 \\
\hline $\mathrm{Cx}$ & & 4 & 4 \\
\hline $\mathrm{Rx}$ & & 3 & 2 \\
\hline Combined therapy & & 9 & 10 \\
\hline Observation & & 0 & 1 \\
\hline State at last follow-up & 40 & & \\
\hline Alive (disease free) & & $14(14)$ & $22(21)$ \\
\hline Died with disease & & 2 & 0 \\
\hline Died no evidence of disease & & 2 & 0 \\
\hline Mean follow-up time (months) & & 49.3 & 50.5 \\
\hline
\end{tabular}

DLBCL, diffuse large B-cell lymphoma; MALT, MALT lymphoma; Op, operation; $\mathrm{Cx}$, chemotherapy; Rx, radiotherapy. diffuse large B-cell lymphomas), with the follow-up periods ranging from 1 to 171 months (mean, 49.9 months). No significant differences between patients with MALT lymphoma and those with diffuse large B-cell lymphoma was observed in age, sex, serum LDH level, stage, treatment, or prognosis $(P>0.05)$. A high frequency of antithyroid antibody was observed not only in patients with MALT lymphoma (13 of 14 patients) but also in those with diffuse large B-cell lymphoma (10 of 12 patients). Regarding clinical stages, $62 \%$ of patients with MALT lymphoma and the same percentage of those with diffuse large B-cell lymphoma remained at stage I E. Patients with either type of lymphoma remained at clinical stage I E or II E, except for one patient with diffuse large B-cell lymphoma who presented at clinical stage IV, which disseminated to the lung, resulting in the patient's death by this disease. Patients presenting at clinical stage II E showed involvement of lymphoma at the cervical, subclavicular, or mediastinal lymph nodes. All patients with MALT lymphoma remained alive during the follow-up period. The patients with diffuse large B-cell lymphoma also demonstrated a good survival rate $(78 \%)$, except that four of them died during the follow-up period. One patient died of diffuse large B-cell lymphoma, another patient died of pneumonia during chemotherapy, and the other two died of causes other than lymphoma or its related complications, with no evidence that the death was attributable to the disease.

\section{Histological and Immunohistochemical Features of MALT Lymphoma and Diffuse Large B-cell Lymphoma of the Thyroid Gland}

MALT lymphomas were composed of centrocytelike cells, most of which (29 of 31 patients) formed lymphoepithelial lesions (Figure 1). Diffuse large B-cell lymphomas showed a diffuse infiltration of large-sized lymphoma cells (Figure 2). Histologically, nine of 27 patients with diffuse large B-cell lymphomas were associated with MALT lymphoma components (Figure 3). Lymphoepithelial lesion was also detected in MALT lymphoma components of diffuse large B-cell lymphomas associated with MALT lymphoma (nine of nine patients). Characteristically, three patients with diffuse large B-cell lymphomas without MALT lymphoma components showed lymphoepithelial lesions, which is seen in MALT lymphoma. In about half of the MALT lymphomas (52\%) and MALT lymphoma components in diffuse large B-cell lymphoma $(50 \%)$, the lymphoma cells involved the germinal centers and formed follicular colonization. Both of the malignant lymphomas showed a B-cell phenotype (CD20 or CD79a) but not a T-cell phenotype (CD3). In addition, the MALT lymphoma cells were negative for CD5 and CD10. 


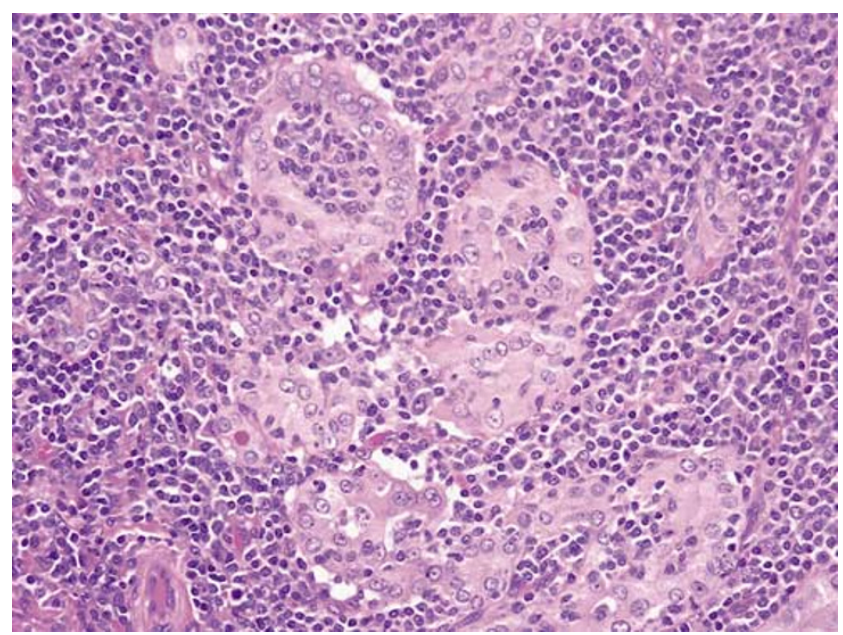

Figure 1 MALT lymphoma (HE). A diffuse proliferation of centrocyte-like cells are seen. Lymphoepithelial lesion is present.

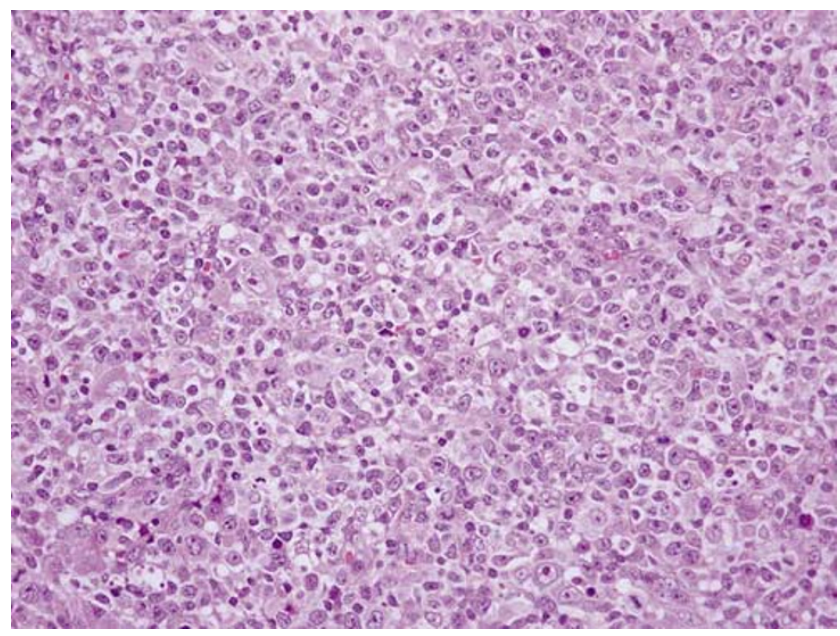

Figure 2 Diffuse large B-cell lymphoma without MALT lymphoma (HE). A diffuse proliferation of large-size lymphoma cells are seen.

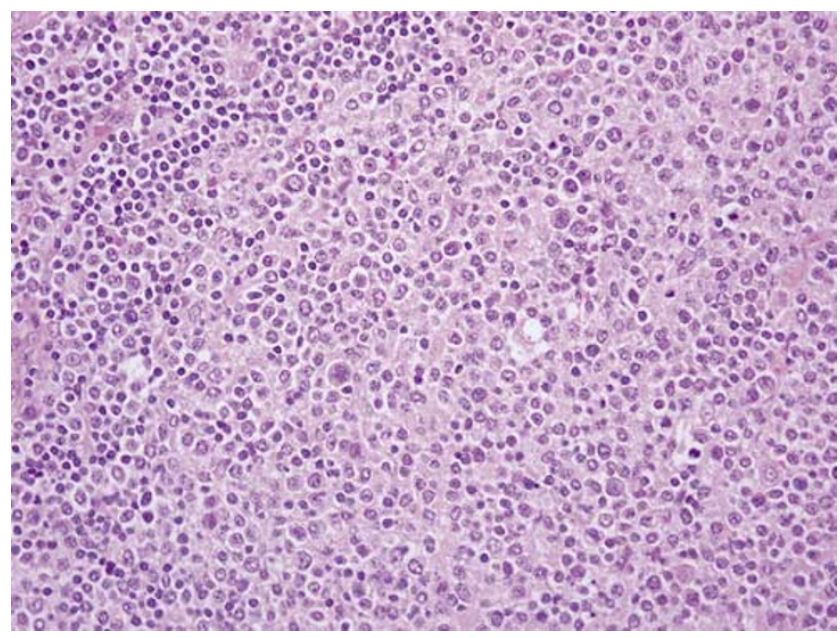

Figure 3 Diffuse large B-cell lymphoma with MALT lymphoma (HE). Large-size lymphoma cells (diffuse large B-cell lymphoma component) on the right side and small—to medium size cells (MALT lymphoma component) on the right side are intermingled.

\section{Detection of $\mathrm{t}(11 ; 18)(\mathrm{q} 21 ; \mathrm{q} 21)$ Chromosomal Translocation}

In the thyroid gland, no $t(11 ; 18)$ was detected in 13 patients with MALT lymphoma or in eight patients with diffuse large B-cell lymphoma, including the patients with MALT lymphoma components.

\section{Detection of IgH Gene Rearrangement Using PCR}

PCR analysis was performed on DNA extracted from the specimens of 31 patients with MALT lymphomas and 27 patients with diffuse large B-cell lymphomas of the thyroid gland. Rearranged $\operatorname{IgH}$ genes were detected in $71 \%$ of malignant lymphomas $(68 \%$ of MALT lymphomas and $74 \%$ of diffuse large B-cell lymphomas).

\section{Analysis of VH Family Usage of MALT Lymphoma and Diffuse Large B-cell Lymphoma}

PCR products from 19 patients (seven with MALT lymphoma and 12 with diffuse large B-cell lymphoma) were unselectively subjected to direct sequencing. In four of these 12 patients, the diffuse large B-cell lymphomas were associated with MALT components, but the components were intermingled and thus were difficult to examine separately. In each of these four patients, DNA was extracted into one tube from the tissue in which two components coexisted, and all of them showed the VH3 family. However, patient 9 had two components separately, and we were able to extract DNA from each component and to sequence each one separately. The two components showed different families: the MALT lymphoma component used the VH4 family, whereas the diffuse large B-cell lymphoma component used the VH3 family (Table 2).

The assignment of the sequences to $\mathrm{VH}$ families of MALT lymphomas and diffuse large B-cell lymphomas without MALT lymphoma components indicated biased usages (Table 2). In the seven patients with MALT lymphomas, three used the VH4 family, whereas most of the patients with diffuse large Bcell lymphomas (eight of nine patients) used the VH3 family, with none using the VH4 family. The MALT lymphomas and diffuse large B-cell lymphomas differed significantly in their use of the VH4 family $(P<0.05)$.

\section{Discussion}

The VH gene has been studied to investigate the lymphomagenesis and cellular origin of B-cell lymphomas. $\mathrm{VH}$ genes are organized into seven $\mathrm{VH}$ gene families based on high sequence homology. ${ }^{15}$ By comparing the frequencies of $\mathrm{VH}$ family usage of MALT lymphomas and diffuse large B-cell lymphomas with peripheral blood B lymphocytes, we were 
Table 2 Sequence analysis of the $I g H$ genes expressed in primary thyroid lymphoma

\begin{tabular}{|c|c|c|c|c|c|c|}
\hline Case no. & Histology & Age (years) & Sex & VH family & Germline VH gene & Identity \\
\hline 1 & DLBCL & 82 & $\mathrm{~F}$ & 3 & VH3-11 & 90 \\
\hline 2 & DLBCL & 88 & $\mathrm{~F}$ & 3 & VH3-11 & 86 \\
\hline 3 & DLBCL & 65 & $\mathrm{~F}$ & 3 & VH3-23 ${ }^{a}$ & 92 \\
\hline 4 & DLBCL & 59 & $\mathrm{~F}$ & 3 & VH3-74 & 90 \\
\hline 5 & DLBCL & 64 & $\mathrm{~F}$ & 3 & VH3-48 & 87 \\
\hline 6 & DLBCL & 72 & $\mathrm{~F}$ & 1 & $V 1-69^{a}$ & 88 \\
\hline 7 & DLBCL & 69 & $\mathrm{~F}$ & 3 & VH3-7 & 94 \\
\hline 8 & DLBCL & 83 & $\mathrm{~F}$ & 3 & VH3-7 & 87 \\
\hline \multirow[t]{2}{*}{9} & DLBCL & 69 & $\mathrm{M}$ & 3 & $\mathrm{~V} 3-30^{\mathrm{a}}$ & 91 \\
\hline & MALT & & & 4 & VH4-31 & 98 \\
\hline 10 & MALT & 47 & $\mathrm{~F}$ & 3 & VH3-7 & 87 \\
\hline 11 & MALT & 43 & $\mathrm{~F}$ & 3 & VH3-20 & 92 \\
\hline 12 & MALT & 75 & M & 3 & VH3-21 ${ }^{\mathrm{a}}$ & 89 \\
\hline 13 & MALT & 86 & $\mathrm{~F}$ & 4 & VH4-39 & 90 \\
\hline 14 & MALT & 63 & $\mathrm{~F}$ & 4 & VH4-34 & 88 \\
\hline 15 & MALT & 73 & $\mathrm{~F}$ & 4 & VH4-61 & 96 \\
\hline 16 & MALT & 83 & $\mathrm{M}$ & 1 & $\mathrm{VH} 1-46^{\mathrm{a}}$ & 84 \\
\hline 17 & DLBCL+MALT & 73 & $\mathrm{M}$ & 3 & VH3-30 & 98 \\
\hline 18 & DLBCL+MALT & 77 & $\mathrm{~F}$ & 3 & VH3-7 & 82 \\
\hline 19 & DLBCL+MALT & 69 & $\mathrm{~F}$ & 3 & VH3-30 & 99 \\
\hline 20 & DLBCL+MALT & 53 & $\mathrm{~F}$ & 3 & VH3-53 & 90 \\
\hline
\end{tabular}

DLBCL, diffuse large B-cell lymphoma; MALT, MALT lymphoma; M, male; F, female.

${ }^{\mathrm{a}} \mathrm{VH}$ genes detected in antithyroid antibody. Data from McIntosh et a ${ }^{19}$ and Chardes et al. ${ }^{20}$

Table 3 Frequency of VH family usage in primary thyroid lymphoma: comparison with lymphoma of other organs and adult peripheral B cells

\begin{tabular}{|c|c|c|c|c|c|c|c|c|c|}
\hline Lymphoma arising in & Histology & $\begin{array}{l}\text { No. of the } \\
\text { analyzed } \\
\text { sequences }\end{array}$ & VH1 (\%) & VH2 (\%) & VH3 (\%) & VH4 (\%) & VH5 (\%) & VH6 (\%) & $V H 7(\%)$ \\
\hline \multirow[t]{2}{*}{ Thyroid gland (this study) } & MALT & 8 & 13 & 0 & 38 & 50 & 0 & 0 & 0 \\
\hline & DLBCL & 9 & 11 & 0 & 89 & 0 & 0 & 0 & 0 \\
\hline Orbital adnexa $^{a}$ & MALT & 10 & 0 & 0 & 70 & 30 & 0 & 0 & 0 \\
\hline Stomach $^{\mathrm{a}}$ & MALT & 9 & 0 & 0 & 56 & 44 & 0 & 0 & 0 \\
\hline Salivary gland $\mathrm{d}^{\mathrm{a}}$ & MALT & 29 & 69 & 0 & 28 & 3.4 & 0 & 0 & 0 \\
\hline Lunga & MALT & 13 & 0 & 0 & 62 & 39 & 0 & 0 & 0 \\
\hline $\begin{array}{l}\text { Adult peripheral blood } \\
\text { B cells }{ }^{\mathrm{a}}\end{array}$ & & & 16 & 8.3 & 65 & 4.6 & 3.5 & 2.7 & 0 \\
\hline
\end{tabular}

DLBCL, diffuse large B-cell lymphoma; MALT, MALT lymphoma; M, male; F, female.

${ }^{\mathrm{a}}$ Data from Mannami et al. ${ }^{16}$

able to examine the nature of $\mathrm{B}$ cells in these lymphomas.

The sequencing study of the $\mathrm{VH}$ gene showed that three of seven patients with MALT lymphomas used the VH4 family. In contrast, most of the diffuse large B-cell lymphomas without the MALT component (eight of nine patients) used the VH3 family and none used the VH4 family. Among the MALT lymphomas of various organs, $\mathrm{VH}$ family usage was found to be biased toward the VH4 family, which has low numbers of $\mathrm{VH}$ genes and which is rare in peripheral blood B lymphocytes (Table 3) (except for VH family usage in the salivary gland, which is characteristically restricted to the VH1 family which is thought to be associated with the rheumatoid factor). ${ }^{16}$ Although MALT lymphomas arise from various extranodal organs, this deviated usage of the $\mathrm{VH}$ families indicates that the pathogenesis of B cells in MALT lymphomas probably came through similar pathways. We clarified that the thyroid MALT lymphoma also belonged in the same category.

The relationship between MALT lymphoma and diffuse large B-cell lymphoma is an interesting one. Chan et al showed that the two components had identical light-chain restrictions in gastric lymphomas and suggested that most if not all diffuse large B-cell lymphomas are the result of an evolution of MALT lymphoma that may have been present for many years. Peng et $a l^{5}$ reported a clonal relationship between diffuse large B-cell lymphomas and MALT lymphomas of the stomach and supported this idea. In contrast, Cabras et $a l^{17}$ and Matolcsy et $a l^{18}$ reported patients with gastric diffuse large 
B-cell lymphoma having a MALT component composed of distinct clones. ${ }^{17,18}$ In the present study, the preferentially used $\mathrm{VH}$ families differed between MALT lymphomas and diffuse large B-cell lymphomas without MALT components, although their clinical backgrounds, such as gender deviation and the presence of Hashimoto disease and/or lymphocytic thyroiditis, were similar.

We also examined the DNA sequences of five patients with diffuse large B-cell lymphomas having MALT components (Table 2). In four of these patients, we found single monoclonal bands but could not determine which components reflected these bands because the two components were too intermingled. These patients might have high-grade transformations, since they had single bands. However, in one patient (patient 9), we were able to examine both components separately. The MALT lymphoma component used VH4, whereas diffuse large B-cell lymphoma used VH3. These findings strongly indicated that lymphocytes belonging to the VH4 family can be MALT lymphomas but not diffuse large B-cell lymphomas, and that at least some diffuse large B-cell lymphomas with MALT components are not high-grade transformations but probably de novo.

A close relationship between MALT lymphoma and Hashimoto's thyroiditis has been reported. ${ }^{3,4}$ We compared the homologous sequences of VH genes of thyroid lymphoma cells to those of the antibody to thyroglobulin and thyroid peroxidase previously reported $^{19,20}$ (Table 2). Three of the eight patients with MALT lymphomas and six of the 13 patients with diffuse large B-cell lymphomas with or without MALT components showed common homologous germline VH genes used by antithyroid antibody. This suggests that both MALT lymphoma and diffuse large B-cell lymphoma are derived from the lymphocytes associated with antithyroid antibody. The high frequencies of antithyroid antibody of patients with both MALT lymphoma and diffuse large B-cell lymphoma also indicated the association of Hashimoto's thyroiditis.

Recently, the $t(11 ; 18)$ chromosomal translocation was identified as a specific chromosomal abnormality in some MALT lymphomas. ${ }^{7-9}$ Moreover, it was reported that $\mathrm{t}(11 ; 18)$ showed variable frequencies at different sites. ${ }^{11}$ In this study, neither MALT lymphoma nor diffuse large B-cell lymphoma of the thyroid gland showed $t(11 ; 18)$. We summarize our data in Table 4 (data on lymphomas in the salivary gland were collected by $\mathrm{SN}$ ). ${ }^{21,22}$ This result was compatible with the previous reports. ${ }^{23,11}$ In short, $t(11 ; 18)$ of the large intestine and ocular adnexa is found at moderate frequencies compared to those of the lung and stomach, which were found at high frequencies. In contrast, $t(11 ; 18)$ is extremely rare in organs such as the thyroid gland and salivary gland, in which autoimmune diseases often arise. This suggests that mechanisms involved in $\mathrm{t}(11 ; 18)$ (q21; q21) have some organ specificity. ${ }^{11}$ These
Table 4 Incidence of the $t(11 ; 18)$ chromosomal translocation in lymphomas from various sites

\begin{tabular}{llcc}
\hline Site & Histology & $\begin{array}{c}\text { No. of } \\
\text { cases }\end{array}$ & $\begin{array}{c}t(11 ; 18) \\
(\%)\end{array}$ \\
\hline Thyroid gland (this study) & MALT & 13 & $0(0)$ \\
& DLBCL & 8 & $0(0)$ \\
Salivary gland $^{\mathrm{a}}$ & MALT & 28 & $0(0)$ \\
& DLBCL & 6 & $0(0)$ \\
Large intestine $^{\mathrm{b}}$ & MALT & 47 & $7(15)$ \\
& DLBCL & 13 & $1(8)$ \\
Ocular adnexa $^{\mathrm{c}}$ & MALT & 23 & $3(13)$ \\
& DLBCL & 14 & $2(14)$ \\
\hline
\end{tabular}

\footnotetext{
${ }^{\mathrm{a}}$ Data from Nakamura.

${ }^{\mathrm{b}}$ Data from Sakugawa et al. ${ }^{21}$

${ }^{\mathrm{c}}$ Data from Takada et al. ${ }^{22}$
}

organ specificities are similar to differences in homing receptors and vascular addressins. ${ }^{24}$

In conclusion, both MALT lymphoma and diffuse large B-cell lymphoma of the thyroid gland occur frequently in elderly females and show favorable outcomes. No significant differences in clinical behavior between MALT lymphoma and diffuse large B-cell lymphoma were found. $t(11 ; 18)$ was rarely associated with the lymphomagenesis of the thyroid lymphoma, and this abnormality seemed to be organ-specific. Our analysis of VH family usage may imply that Hashimoto's thyroiditis is associated with both subtypes, but the groups differed in which VH families they used.

\section{Acknowledgements}

We thank Dr S Fujiwara, Dr K Hayashi, Dr S Mano, Dr A Miyata, Dr K Miyatani, Dr Y Mochiduki, Dr I Murakami, Dr S Nose, Dr K Taguchi, Dr Uchiyama, Dr I Yamadori, and Dr M Yoshida for providing lymphoma samples, and Ms M Okabe for her expert technical assistance.

\section{References}

1 Isaacson P, Norton AJ. Malignant lymphoma of the thyroid gland. In: Extranodal Lymphomas. Churchill Livingstone: Edinburgh, 1994, pp 103-115.

2 Lymphoma Study Group of Japanese Pathologists. The world health organization classification of malignant lymphomas in Japan: incidence of recently recognized entities. Lymphoma Study Group of Japanese Pathologists. Pathol Int 2000;50:696-702.

3 Holm LE, Blomgren H, Lowhagen T. Cancer risks in patients with chronic lymphocytic thyroiditis. New Engl J Med 1985;312:601-604.

4 Hyjek E, Isaacson PG. Primary B cell lymphoma of the thyroid and its relationship to Hashimoto's thyroiditis. Hum Pathol 1988;19:1315-1326.

5 Peng H, Du M, Diss TC, et al. Genetic evidence for a clonal link between low and high-grade components in 
gastric MALT B-cell lymphoma. Histopathology 1997; 30:425-429.

6 Chan JK, Ng CS, Isaacson PG. Relationship between high-grade lymphoma and low-grade B-cell mucosaassociated lymphoid tissue lymphoma (MALToma) of the stomach. Am J Pathol 1990;136:1153-1164.

7 Auer IA, Gascoyne RD, Connors JM, et al. $\mathrm{t}(11 ; 18)(\mathrm{q} 21 ; \mathrm{q} 21)$ is the most common translocation in MALT lymphomas. Ann Oncol 1997;8:979-985.

8 Dierlamm J, Wlodarska I, Michaux L, et al. Genetic abnormalities in marginal zone B-cell lymphoma. Hematol Oncol 2000;18:1-13.

9 Ott G, Katzenberger $\mathrm{T}$, Greiner A, et al. The $\mathrm{t}(11 ; 18)(\mathrm{q} 21 ; \mathrm{q} 21)$ chromosome translocation is a frequent and specific aberration in low-grade but not high-grade malignant non-Hodgkin's lymphomas of the mucosa-associated lymphoid tissue (MALT) type. Cancer Res 1997;57:3944-3948.

10 Starostik P, Patzner J, Greiner A, et al. Gastric marginal zone B-cell lymphomas of MALT type develop along 2 distinct pathogenetic pathways. Blood 2002;99:3-9.

11 Ye H, Liu H, Attygalle A, et al. Variable frequencies of $t(11 ; 18)(q 21 ; q 21)$ in MALT lymphomas of different sites: significant association with CagA strains of $\mathrm{H}$ pylori in gastric MALT lymphoma. Blood 2003;102: 1012-1018 (E-pub 2003 April 2003).

12 Isaacson PB, Müller-Hermelink F, Nathwani HK, et al. Extranodal marginal zone B-cell lymphoma of mucosaassociated lymphoid tissue (MALT lymphoma). In: Jaffe ES, Stein H, Vardiman JW (eds). Tumours of Haematopoietic and Lymphoid Tissues. World Health Organization Classification of Tumors, Pathology and Genetics. IARC Press: Lyon, 2001, pp 157-160.

13 Nakamura N, Hashimoto Y, Kuze T, et al. Analysis of the immunoglobulin heavy chain gene variable region of CD5-positive diffuse large B-cell lymphoma. Lab Invest 1999;79:925-933.

14 Inagaki H, Okabe M, Seto M, et al. API2-MALT1 fusion transcripts involved in mucosa-associated lymphoid tissue lymphoma: multiplex RT-PCR detection using formalin-fixed paraffin-embedded specimens. Am J Pathol 2001;158:699-706.
15 Cook GP, Tomlinson IM. The human immunoglobulin VH repertoire. Immunol Today 1995;16:237-242.

16 Mannami T, Yoshino T, Oshima K, et al. Clinical, histopathological, and immunogenetic analysis of ocular adnexal lymphoproliferative disorders: characterization of malt lymphoma and reactive lymphoid hyperplasia. Mod Pathol 2001;14:641-649.

17 Cabras AD, Weirich G, Fend F, et al. Oligoclonality of a 'composite' gastric diffuse large B-cell lymphoma with areas of marginal zone B-cell lymphoma of the mucosa-associated lymphoid tissue type. Virchows Arch 2002;440:209-214.

18 Matolcsy A, Schattner EJ, Knowles DM, et al. Clonal evolution of B cells in transformation from lowto high-grade lymphoma. Eur J Immunol 1999;29: 1253-1264.

19 McIntosh R, Watson P, Weetman A. Somatic hypermutation in autoimmune thyroid disease. Immunol Rev 1998;162:219-231.

20 Chardes T, Chapal N, Bresson D, et al. The human anti-thyroid peroxidase autoantibody repertoire in Graves' and Hashimoto's autoimmune thyroid diseases. Immunogenetics 2002;54:141-157 (E-pub 2002 May 2002).

21 Sakugawa ST, Yoshino T, Nakamura S, et al. API2MALT1 fusion gene in colorectal lymphoma. Mod Pathol 2003;16:1232-1241.

22 Takada S, Yoshino T, Taniwaki M, et al. Involvement of the chromosomal translocation $\mathrm{t}(11 ; 18)$ in some mucosa-associated lymphoid tissue lymphomas and diffuse large B-cell lymphomas of the ocular adnexa: evidence from multiplex reverse transcriptase-polymerase chain reaction and fluorescence in situ hybridization on using formalin-fixed, paraffin-embedded specimens. Mod Pathol 2003;16:445-452.

23 Kalla J, Stilgenbauer S, Schaffner C, et al. Heterogeneity of the API2-MALT1 gene rearrangement in MALT-type lymphoma. Leukemia 2000;14:1967-1974.

24 Liu YX, Yoshino T, Ohara N, et al. Loss of expression of alpha4beta7 integrin and L-selectin is associated with high-grade progression of low-grade MALT lymphoma. Mod Pathol 2001;14:798-805. 